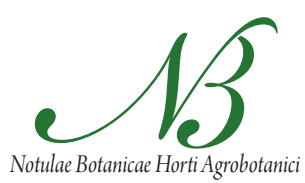

Cluj-Napoca

\title{
The Future of Professional Forestry Education: Trends and Challenges from the Malaysian Perspective
}

\author{
Jegatheswaran RATNASINGAM¹, Florin IORAS², Claudia Cristina VACALIE, Lu WENMING ${ }^{4}$ \\ ${ }^{1}$ Faculty of Forestry, Universiti Putra Malaysia, 43400 UPM, Serdang, Selangor, Malaysia; jegaratnasingam@yahoo.com \\ ${ }^{2}$ Institute for Sustainable Studies, Buckinghamshire New University, Queen Alexandra Road, High \\ Wycombe, HP 112 JZ Buckinghamshire,United Kingdom; florin.ioras@googlemail.com \\ ${ }^{3}$ Faculty of Silviculture and Forest Engineering, Transilvania University of Brasov, 1Sirul Beethoven, 2200 Brasov, Romania; cris_d84@yahoo.com \\ ${ }^{4}$ Chinese Forestry Academy, Wanshoushan Hou, Haidian District, Beijing 100091, P. R. China; luwenmingcaf@126.com
}

\begin{abstract}
The traditional forestry education schemes are no longer sufficient to train professional foresters to manage the forest resources in a changing world. Even in forest-rich nations such as Malaysia, the challenges faced by forestry education are growing. The declining student enrolment and interests in the field must be stopped, if the field is to remain viable. The roles played by the forest have shifted from purely commercial products exploitation to environmental and social centric. In this context, forestry education will need to be restructured to impart the necessary knowledge and skills to the foresters to enable them to perform up to expectation in the field.
\end{abstract}

Keywords: economics, education, environmental, forestry, training, social

\section{Introduction}

The forests of the world are complex ecosystems, supporting the simplest to the most complex life forms. Yet its biodiversity is both its strength and adversary, as forest produces (which includes timber and non-timber products) are indiscriminately exploited by man for economic returns. Even, the environmental and recreational services played by the forests have become potential economic sectors to many countries, especially in the tropics (Ratnasingam, 2011). Although international agencies such as the Food and Agriculture Organization (FAO) of the United Nations and the International Tropical Timber Organization (ITTO) continue to fund development projects with the aim of achieving sustainable management of the forest resources in many parts of the developing world, the success on the ground depends on the availability of a numbers of different expertise and professionals in the host country. The necessary human capital to manage the forest and its resources must be developed through a proper education scheme (Ratnasingam et al., 2011).

In many parts of the world, students are exposed to the forest very early in their schooling days through the teaching of geography and biology, but the depth of coverage is often limited to the main produces and its contribution to the country's economic wealth. Although, a focused approach to forestry as a professional career study program becomes an option at the college and university levels, producing a sufficient number of professional foresters is becoming a challenge in many parts on the world. There- fore, this paper attempts to examine the trends and challenges in forestry education worldwide, with an emphasis on the state of forestry education in Malaysia, which is regarded as an emerging powerhouse in sustainable forestry practices and the value-added forest products sector (Attah et al., 2009; Ratnasingam et al., 2008; Ratnasingam et al., 2011).

\section{Traditional Forestry Education}

Professional forestry education was introduced almost 200 years ago (Daramola, 2010) upon the realization of the importance of the forest and its resources. Since then, forestry education system has evolved incorporating learning, researching and training activities for the human capital development for the forestry sector. By the late $19^{\text {th }}$ century, forestry one of the preferred choice of professional career education as forestry and its related sectors became an important revenue earner for many forest-rich countries around the world (Daramola, 2010). In fact, forest education can be schematically shown to encompass four levels of participation as suggested by Vanclay (1996), with each level playing a particular role in ensuring the success of the forestry sector (Fig. 1).

Generally, forestry education at tertiary level is structured to produce professional foresters. Leslie et al. (2006) stated that school leavers who selected forestry academic programs at universities were driven by the opportunity to work outdoors, their interest in managing biodiversity of natural environment, creating and managing wood 
resource and potential to interact and work with the forest-based communities. Against this background, the traditional forestry programs prepared the students with a strong foundation in a number of core academic disciplines, and subsequently trained them in the professional context for the forestry sector (Brown, 2003).
2008). This consequential reduction in student enrolment in forestry programs has led to considerable uncertainty in the forestry fraternity worldwide (Nair, 2004).

The declining student enrolment in forestry programs have been notable in countries, such as Great Britain (Burley, 2001), Canada (Innes, 2005), Australia (Vanclay,

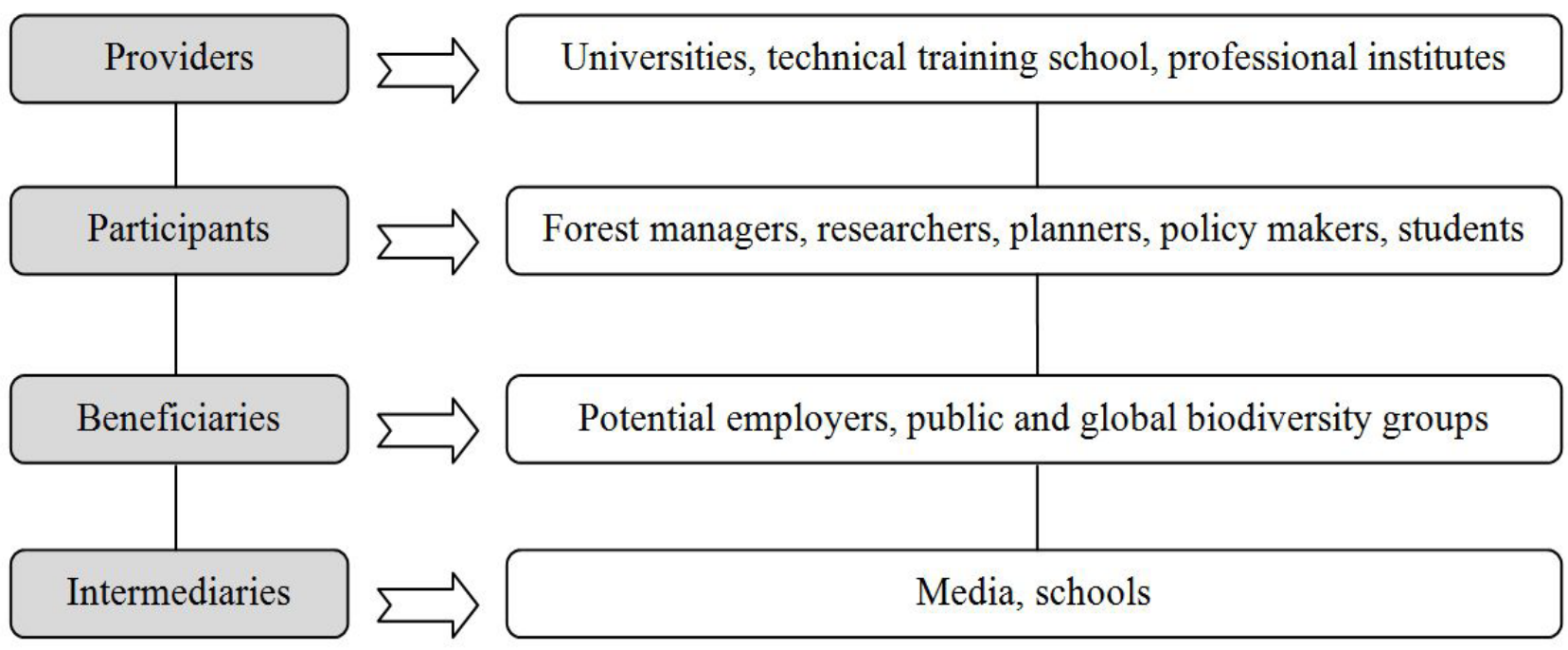

Fig. 1. Participation Levels in the Forestry Education System

In many forest-rich nations, forestry education has remained with this traditional model, usually introduced by the colonizing nations or having been emulated from other nations in the region. With the global change in forest cover and its role, the traditional forestry education model appears to be ill equipped to produce the necessary human capital to cope with the emanating challenges (Ratnasingam et al., 2011). Inevitably, forestry education is in transition all over the world, and under growing pressure to remain relevant as a professional career education.

\section{Challenges in Forestry Education}

Forestry education in many universities throughout the world is currently suffering from serious drawbacks. Hence, it is no surprise that the future of forestry education in tertiary institutions has attracted overwhelming debates since the late 1990s (Arevalo et al., 2012). The core contention in these debates is whether forestry education is acceptable as university academic program or is sufficient as a technical subject of a non-university diploma level (Innes and Ward, 2010).

Several critical reasons have continuously cited for the problems faced by forestry education. High on the list of reasons is the reducing interest in forestry academic programs. School leavers have a tendency to choose careers with high salary, such as business, finance, engineering and computer and information technology (ICT), which offers a grand life style that may not be realized by choosing a career in the forestry sector (Leslie et al., 2006; Nyland,
2005) and United States (Green 2006; Nyland, 2008). Further, forestry institutions in small island nations such as Fiji and Papua New Guinea under the commonwealth group of nations have ceased operation (Kanowski, 2001). Even in African countries, forestry appears to be on the decline due to inconsistent student enrolments (Temu et al., 2006). Against the declining number of professional foresters produced in many countries, there is an increasing dependency on expatriate foresters in some countries. For instance, Vanclay (2005) pointed out that Australian employers have been increasingly appointing entry-level foresters from other countries as a result of insufficient graduate foresters.

On the other hand, the fate of forestry education in Asia, particularly in the South East Asian region appears to be more promising. With declining student enrolment in the Philippines and a stagnant student intake in Indonesia, all other nations in the region (Malaysia, Laos, Thailand and Vietnam) has seen rising student enrolments in forestry programs (Temu et al., 2005).

As a result of the falling numbers of students in forestry programs in many parts on the world, Arevalo et al., (2010) carried out a survey in European Union (EU) countries to evaluate the changing needs of professional foresters, and the ensuing reforms that university-level forestry programs must undertake. It was found that employers and universities provided similar assessments regarding the importance of competencies and the gap between their achievements in training professional foresters and the market needs. 
14

Besides that, the number of female students in forestry programs is generally small (Arevalo et al., 2012; Leslie et al., 2006; Storch, 2011; Temu et al., 2005). Women are generally not so keen to pursue forestry programs, which is dominated by men in many parts on the world. Storch (2011) revealed that even when women are in forestry service, they are primarily employed in administrative and support roles, while the professional women foresters are often given specialist roles such as research or first-line junior management positions.

Vanclay (1996) postulated several reasons that contributed to the changing fate and challenges faced by professional forestry education throughout the world. Among the important reasons cited were:

- The increasing world population which will create a greater demand for forest resources, which could be in the range of $80 \%$ of the present net productive capacity;

- The decreasing global biodiversity by at least $12 \%$ over the next two decades;

- The critical reduction of clean water, food, space and other resources;

- The excess in domestic and industrial waste;

- The ensuing climate change due to greenhouse gasses emissions and other atmospheric pollutants;

Accordingly, professional foresters are ill-equipped to meet the above challenges based on the present forestry education programs, which contributes to the redundancy of such expertise in the prevailing condition. Meanwhile, Arevalo et al. (2012) attributed the growing gaps between the existing forestry education and the market needs, to several factors:

- The apparent shift towards the social, cultural and ecological values of the forests;

- The globalisation and internationalisation processes which allows many multinational industries and environmental agencies / groups to operate easily across borders;

- The growing competition from graduates from other nature, life and botany-related disciplines;

- The changing demands of employers with respect to the competencies and experiences that are sought from forestry graduates.

Despite the growing discontent, forestry programs in many parts of the world have not been restructured to meet market demands. In reality, there is an ample evidence to suggest that many of the forestry programs still resemble the Oxford syllabus, which is older than a century (Vanclay, 2007). To put it in another way, forestry academic, teachers and trainers have not fully adopted to keep up with these changes. Guariguata and Evans (2010) reported that forestry graduate students from tropical countries have been unable and ill-equipped to fit with local stakeholders in technical and economic aspects, participatory approaches to forest resource use and respond effectively to global forestry paradigms. Further, many forestry institutions in the African continent are lagging behind in the forestry curricula (Temu et al., 2005).
Surprisingly the situation is no better in the developed nations, where in some universities in the United States of America, forestry programs are offered at the environmental sciences schools as young people tend to show greater affinity for environmental movements (Nyland, 2008). The survey by Arevalo et al. (2010) showed that universities in European Union (EU) countries have significant gaps in forestry courses, such as environmental services, bioenergy, products trade and marketing, economics and governance, as the European universities emphasized more on generic competencies such as the capacity to learn. The forestry programs lacked applied components and produces graduates who do not have idea of what to do with their qualifications in economic terms. Miller (1992) reported that besides the reducing numbers of graduates, forestry-related employers in the United Kingdom have noticed declining quality among graduates. Under such circumstances, potential employers preferred applicants with some business acumen, marketing knowledge as well as the ability to work well with people. Leslie et al. (2006) claimed that the argument for a need for professional forestry qualification was unfounded, as graduates from other disciplines were also capable of doing the tasks of foresters.

In the United Kingdom for instance, the private sector prefer to employ forestry degrees but the Forestry Commission believes that forestry graduates are not necessary for management positions within the organization (Leslie et al., 2006). In recent years, many European and North American universities have highlighted the dwindling numbers of government employment opportunities for forestry graduates, which forces the graduates to seek employment outside the forestry sector. Although there are employment opportunities in the private forestry and nongovernmental organizations, these are limited and require specific skills (Temu et al., 2005). The fact that despite the significant change in attitude towards the forests, in an effort to preserve its complex biodiversity, environment and the wildlife sanctuaries, these have not been translated into greater employment opportunities for forestry graduates.

It is therefore apparent that the needs of the market for professional foresters are changing. Although there is a global need for forestry graduates, there appears to be a lack of job opportunities for forestry graduates. According to Ratnasingam and Ioras (2006), the fastest growing job opportunity for forestry graduates are in many nontraditional sectors, such as non-governmental forestry and environmental pressure groups. The observable trend in the job market for professional foresters was presented by Temu et al. (2005), as illustrated in Fig. 2.

In retrospective, professional forestry is in transition, and whether it adapts and survives in the new market realities will very much depend on the restructuring of the forestry education in many parts of the world. Perhaps, an analysis of the forestry education program in a developing country would provide the necessary directions for change that could be emulated elsewhere. 


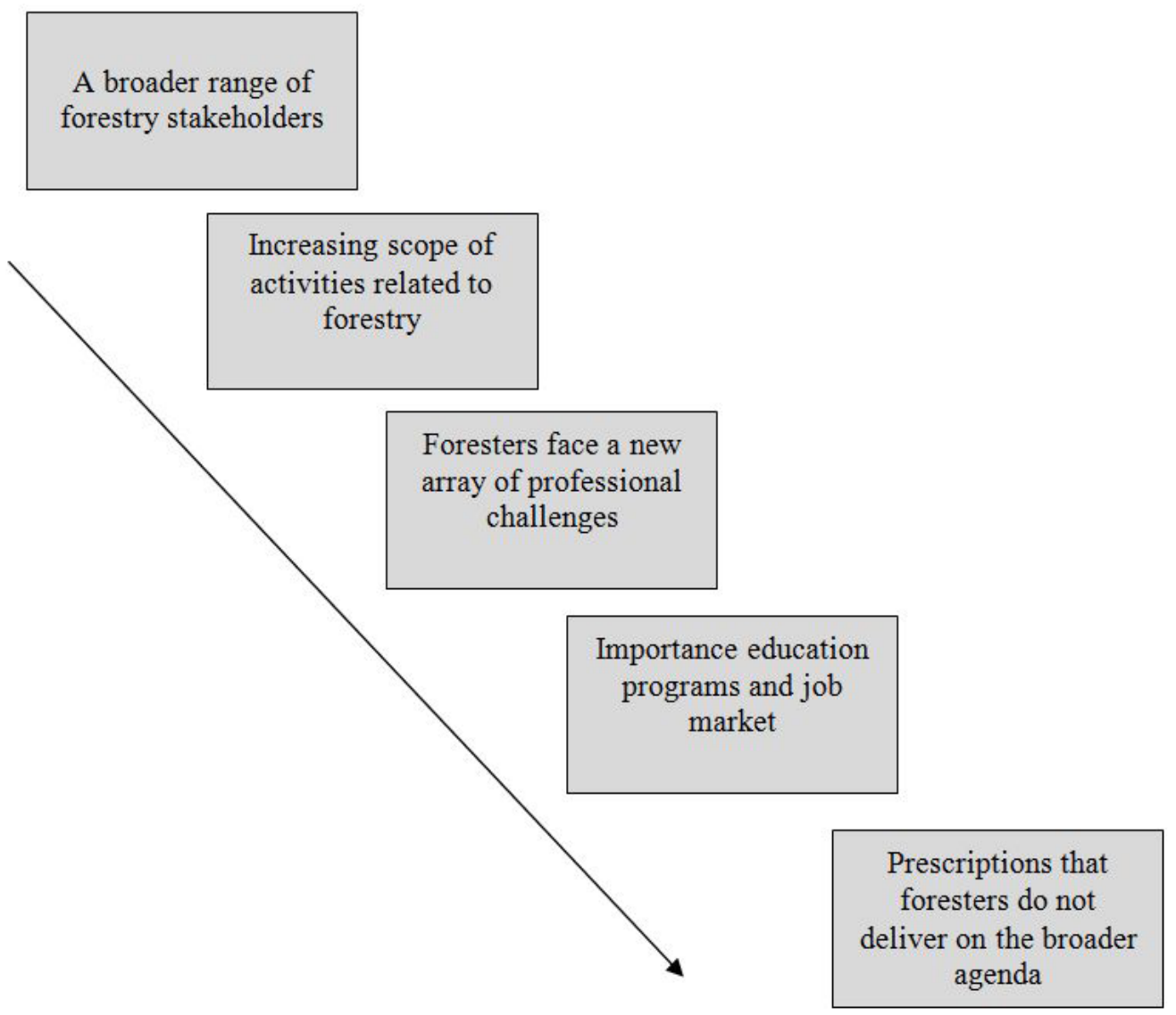

Fig. 2. The Forester's Professional Challenges

\section{The Malaysian Experience in Forestry Education}

Professional forestry education in Malaysia was installed by the British colonial master's in the early 1900s, in what was called Malaya at that time. It appeared that the forestry service at that time was dominated by those who had undergone a short term education and training in any forest-related courses and was awarded a certificate of competency (Ratnasingam and Ioras, 2006). The Forestry Department in Peninsular Malaysia (FDPM) offered a wide range of forestry education from introductory training programs to continuing education programs, which was aimed to serve as a re-freshening program to meet the demand of the forestry services in the country at that time (Singham, 1977). The courses offered were categorized to cater for specific target groups, which were:

- Industrial and Manual Group

- General forest labourer certificate course

- Specialized forest labourer course

- Clerical and Technical Group

- Certificate course for foresters

- Advanced courses for foresters and forest rangers

- Specialized courses for foresters and forest rangers

- Logging training course

- Timber grading course

- Workshops for clerks serving in forest offices
- Executive and Sub-professional Group

- Diploma course at the Forestry College in Kepong

- Probationary sub-professional officers' orientation course

- Probationary sub-professional officers' operational course

- Course in law and court procedure

- Course in logging

- Professional and Managerial Group

- Probationary professional officers' orientation course

- Course in law \& court procedure

- Ad-hoc Courses at the Timber Research Laboratory

- Sawmilling course

- Seasoning / Drying course

- Preservative treatment course

These courses at the Forestry Department were sufficient to train the relevant human capital for the forestry services in the country at that time, which was primarily focused on the extraction of timber resources and other forestry produces for the British colonial masters (Jomo et al., 2004). In fact, the close correlation between the forestry education programs that existed and the primary role of the forest to the nation, underlines the notion that forestry will always remain in mainstream economics throughout 
Tab. 1. Forestry Education in Faculty of Forestry, University Putra Malaysia (UPM)

\begin{tabular}{|c|c|c|c|c|}
\hline Time Frame & Focus & Major Concern & Programs Offered & Total Graduates \\
\hline $1957-1980$ & $\begin{array}{l}\text { Timber Production and } \\
\text { Agriculture Expansion }\end{array}$ & $\begin{array}{l}\text { Socio-Economic } \\
\text { Development }\end{array}$ & Forestry & 94 \\
\hline $1981-1990$ & $\begin{array}{l}\text { Sustainable Forest } \\
\text { Management }\end{array}$ & $\begin{array}{l}\text { Forest Resources } \\
\text { Conservation }\end{array}$ & Forestry & 218 \\
\hline $1991-2000$ & Forest Conservation & $\begin{array}{l}\text { Mitigating Environmental } \\
\text { Degradation }\end{array}$ & Forestry & 718 \\
\hline $2001-2010$ & $\begin{array}{l}\text { Biodiversity } \\
\text { Conservation }\end{array}$ & $\begin{array}{l}\text { Genetic Resources } \\
\text { Conservation }\end{array}$ & $\begin{array}{c}\text { Forestry } \\
\text { Wood Science \& Technology }\end{array}$ & 1582 \\
\hline 2010 onwards & Plantation Forestry & $\begin{array}{l}\text { Raw Materials Supply } \\
\text { Base Expansion }\end{array}$ & $\begin{array}{c}\text { Forestry } \\
\text { Wood Science and Technology } \\
\text { Parks and Recreation Management }\end{array}$ & 254 \\
\hline
\end{tabular}

the world, amidst it's continuously changing focus (Ratnasingam and Ioras, 2006; Ratnasingam et al., 2011).

Professional forestry education in Malaysia began in 1976, when the Faculty of Forestry at University Putra Malaysia (UPM) was established (Hadi, 1977). The forestry curricula at the faculty has been restructured to meet the changing demands of the sector, both public and private (Tab. 1).

Although in many parts of the world, student enrolment in forestry programs are on the decline, this is not the case in Malaysia. Fig. 3 show that there is a general upward trend in student enrolment in the forestry programs, although the pattern cannot be categorized as being consistent. One of the most important reasons for this encouraging student enrolment is the fact that there is an ever increasing cohort of students supplied from related diploma programs from other institutions and the prevailing education policy that makes tertiary education accessible to all (Jomo et al., 2004).

The rapid expansion of the wood-based industry, particularly the added-value product manufacturing, through the implementation of the $1^{\text {st }}(1986-1995), 2^{\text {nd }}(1996-$
2005) and $3^{\text {rd }}$ (2006-2015) Industrial Master Plans, created the demand for wood technologists. This led to the introduction of the Wood Science and Technology program in 2006, which aimed to produce skilled human capital to take the responsibility to transform wood materials into added-value products. Although, Universiti Teknologi Mara (UiTM) had a long standing diploma program in wood technology since 1973, it was felt that there would be no overlaps between the new program established at the Faculty of Forestry at Universiti Putra Malaysia and the ever expanding industrial-base with a workforce of almost 75,000 would be able to absorb these graduates (Ratnasingam et al., 2011). Soeradji (1977) pointed out that professional foresters are usually concerned with providing the wood material, and not with the conversion/ processing of forest products. Further, specialized wood technology knowledge was deemed not necessary for foresters to carry out their tasks in the field.

In 1998, another professional forestry education program was established at the School of International Tropical Forestry at University Malaysia Sabah. There were four programs offered at the school, namely: International

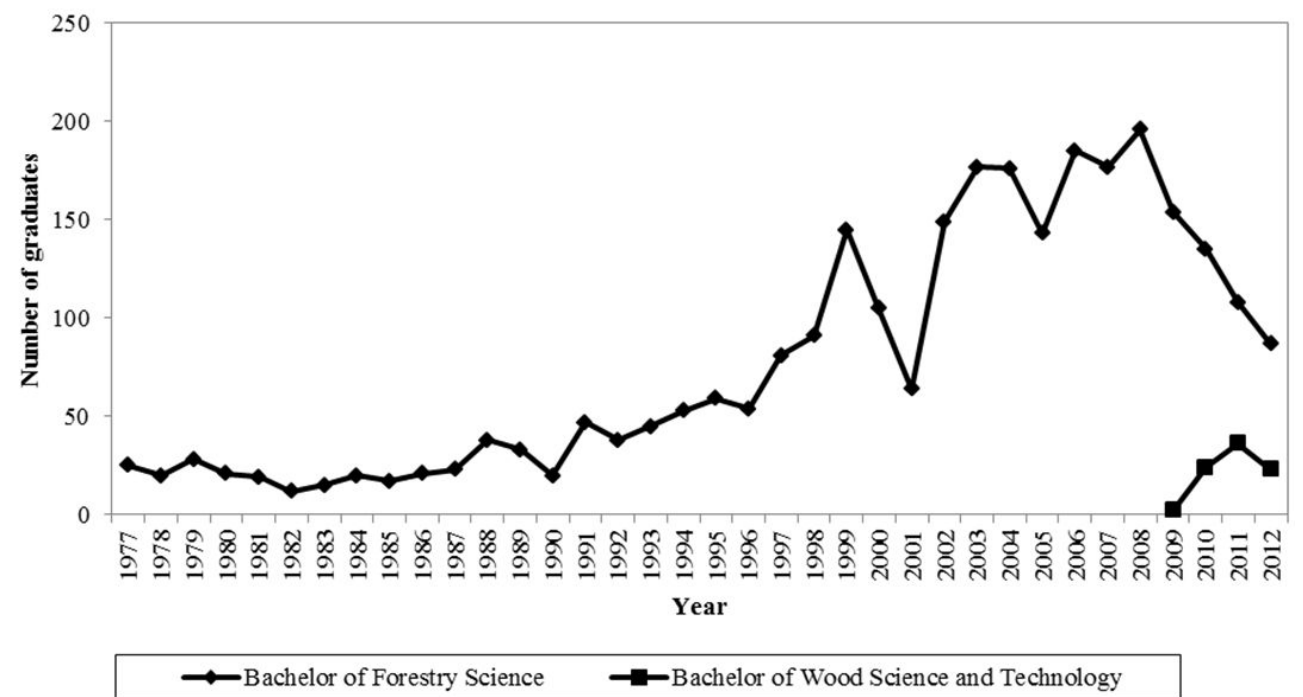

Fig. 3. Number of Graduates from Faculty of Forestry, UPM (1977-2012) 


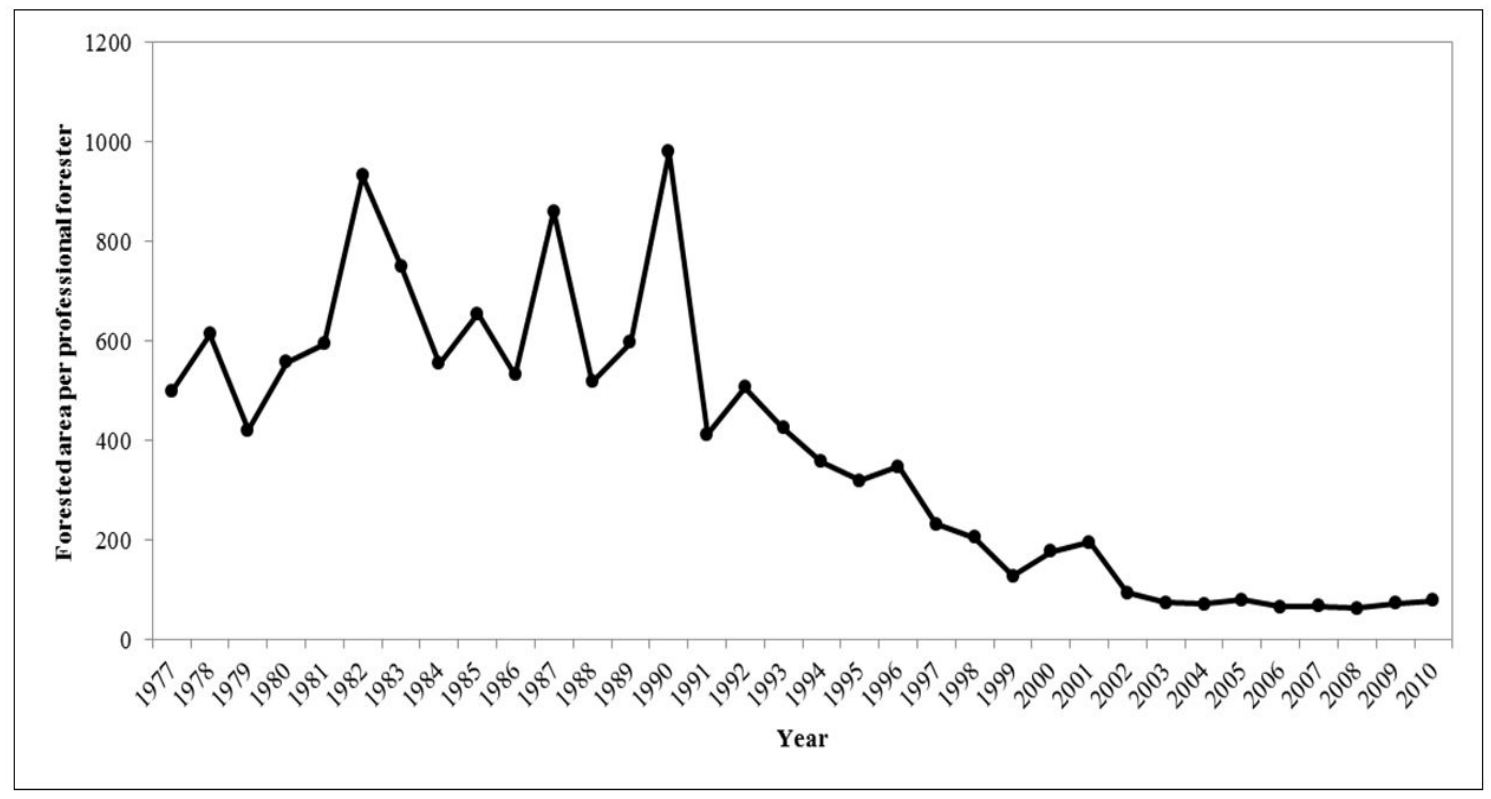

Fig. 4. Forested Area per Professional Forester in Malaysia (1977-2010)

Tropical Forestry, Nature Parks and Recreation, Forest Plantation and Agro-Forestry as well as Wood Fibre Technology (Trockenbrodt, 2003). The number of student enrolment in these four programs increased progressively to 140 over the years (Kammersheidt et al., 2007).

There appears to be an ample evidence to support the notion that the forestry education in Malaysia has been shaped by the foreseen demand for professionals from the rapidly expanding forestry sector in the country. Wellman (1987) and Hadi (1997) emphasized that it was essential that the number of students graduating at the end of their forestry studies matched as near as possible the requirement of the country. In fact, Malaysia has carved a niche as a leader in sustainable forest management in the tropical region, and fuelled by an expanding forestry industries, the projection for potential employment opportunities were encouraging. With almost 20 million hectares of land under natural forest cover coupled with almost 4.8 million hectares of land under plantation tree crops such as rubber, oil palm and forest plantations, it was apparent that forestry will remain a vibrant economic sector in the country for many years to come (Kammesheidt et al., 2007).

\section{Forestry Education in Malaysia-Myths and Realities}

The fact that most of the 11.82 million hectares of production forests have been heavily logged at least once, and hence are poorly stocked with commercial species above the legal diameter cutting limit does not augur well for the future supply of wood resources in the country. Inevitably, plantation wood resources, especially Rubberwood ( $\mathrm{He}$ vea brasiliensis Müll.Arg.) has dominated the added-value wood products sector catering for almost 2.5 million $\mathrm{m}^{3}$ of the wood resource needs. In recent years, up to 0.5 million $\mathrm{m}^{3}$ of wood resources have also been imported to cater for the needs of industrial processing within the country (Department of Statistics, 2012; Ratnasingam, 2012).

In retrospective, it appears that the forest area per professional forester has been steadily declining over the years, which explains the relatively low rate of recruitment of foresters by the Forestry Department in the country (Fig. 4). On the other hand, there should be ample opportunities for wood technologists to find employment in the woodbased industry as the number of mills per graduate wood technologist stands at a staggering rate of 30:1 (Fig. 5).

However, a report from the German Agency for Technical Cooperation (GTZ) on the demand for professional forestry graduates for the forestry sector in Peninsular Malaysia, Sabah and Sarawak revealed findings to the contrary of the general perception. The employment prospects for forestry graduates during the period 2006-2010 in the upstream and downstream sectors are depicted in Fig. 6(a) and Fig. 6(b) respectively.

Based on the GTZ report (Hann-Schilling, 2004), it was found that the employment opportunities for profes-

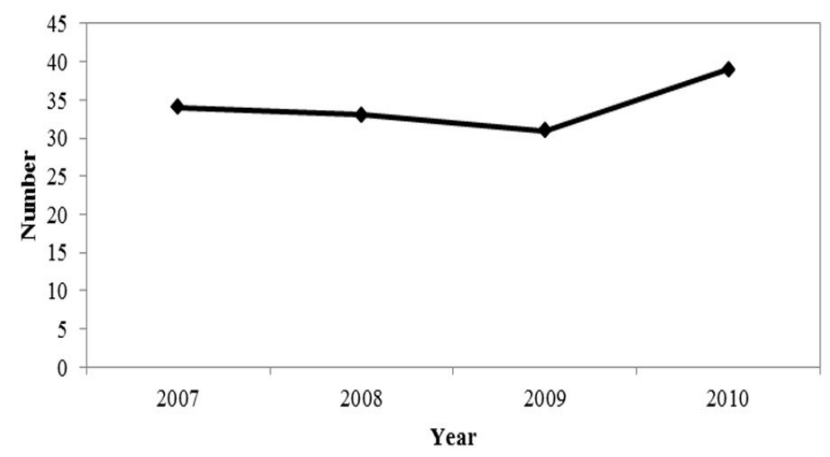

Fig. 5. Number of Wood-Based Mills per Wood Technologist in Malaysia (2007-2010) 
18

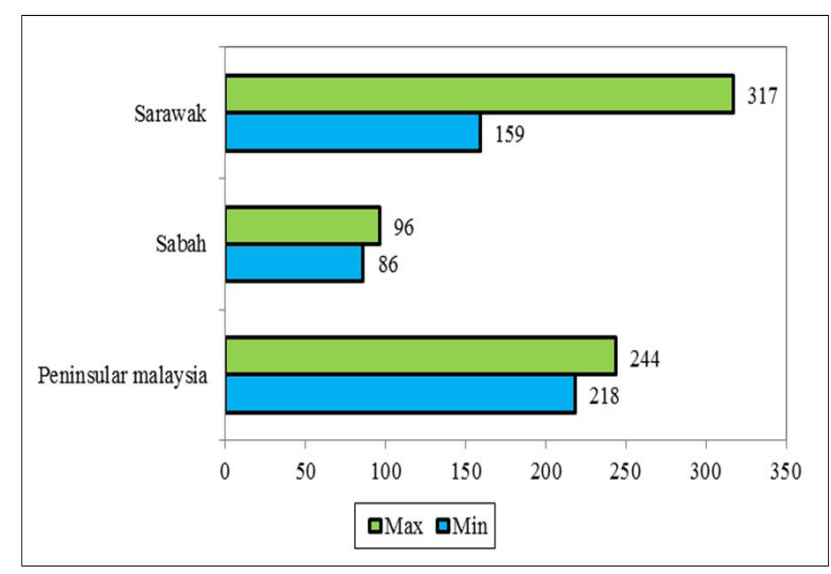

(a)

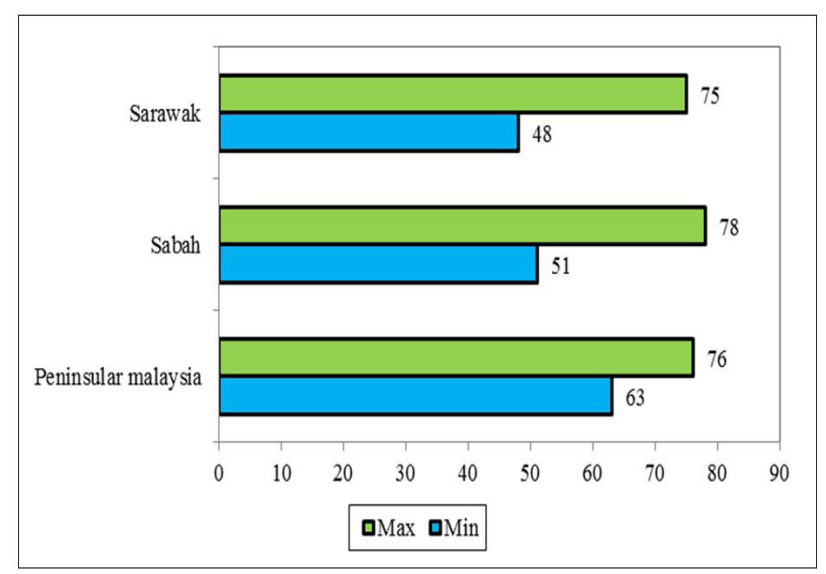

(b)

Fig. 6. Employment Prospects for Forestry Graduates in the Upstream (a) and Downstream (b) Sectors in Malaysia

sional foresters were limited in Peninsular Malaysia, but was more promising in the states of Sabah and Sarawak, which had very vibrant upstream forestry activities. On the other hand, potential downstream sector employers preferred graduates who have expertise in industrial production processes, factory management, machinery technology, automation and product design, which are courses not well covered in the existing curricula (Hann-Schilling, 2005).

The dilemma faced by forestry graduates in Malaysia has been highlighted previously by Ratnasingam et al. (1997), Ratnasingam and Ioras (2007, 2009), Ratnasingam et al. (2010). The prevailing mismatch between the market needs and the graduate's capability were restricting employment opportunities in the forestry sector, so much so that a large part of forestry graduates had to seek employment in other non-forestry sectors. Although efforts have been taken to address some of these skills mismatch, the restructuring of the curricula is far from satisfactory so much so that marketing forestry programs is becoming increasingly difficult in a country that is forest-rich. In reality, the forestry sector is Malaysia has emerged as a low-wage sector, with limited potential for value-addition (Tab. 2). This offers limited career growth prospects to the younger generation, who are accustomed to many other high salary sectors that are more lucrative to pursue. Inevitably, the bright minds among the younger generation often do not choose forestry as the preferred field of study in universities, and thereafter to pursue a professional forestry career.

It is therefore apparent that forestry education in Malaysia is also in transition, as it is faced with a younger generation that appears to be less enthusiastic about forestry and the environment, coupled with its low-paying and limited career growth prospects. In the meantime, the saving grace appears to be the interventionist education policy in the country, which ensures that the student enrolment in forestry programs stay above the minimum, thus making such programs viable.

\section{Forestry Education for the Future}

Against the background of globalization, democratization of education, the rapid progress in science and technology and the growing environmental concern, it is undeniable that higher education sector, which includes forestry education, will have to be transformed (Andersen et al., 2002).

Due to importance of forestry, the traditional forestry education will have to shift towards social forestry, community forestry, and environmental conservation, with renewed emphasis on the social, economic and environmental aspects of the forest (Ratnasingam and Ioras, 2006). Hence, a review of the forestry education curriculum is

Tab. 2. Employment Statistics of Forestry and Wood Technology Graduates

\begin{tabular}{ccccccc}
\hline Year & $\begin{array}{c}\text { Forested area } \\
\text { per capita (ha) }\end{array}$ & $\begin{array}{c}\text { Forestry revenue } \\
\text { (US\$ million) } \\
\text { per forester }\end{array}$ & $\begin{array}{c}\text { Value added } \\
\text { per employee } \\
\text { (US\$) }\end{array}$ & $\begin{array}{c}\text { Average monthly } \\
\text { salary (US\$) } \\
\text { with five years } \\
\text { of experience }\end{array}$ & $\begin{array}{c}\text { No. of foresters } \\
\text { per 1000 workers } \\
\text { employed }\end{array}$ & $\begin{array}{c}\text { No. of wood } \\
\text { technologist per 1000 } \\
\text { workers employed }\end{array}$ \\
\hline 1995 & 0.90 & 0.2 & 14,000 & 570 & 7 & 5 \\
2000 & 0.80 & 0.1 & 11,000 & 650 & 5 & 4 \\
2005 & 0.78 & 0.06 & 10,000 & 750 & 4 & 3 \\
\hline 2010 & 0.74 & 0.02 & 9.300 & 890 & 3 & 3 \\
\hline
\end{tabular}

Source: Ratnasingam et al. (2010) 
essential for the development of a restructured forestry program which is both relevant and of acceptable quality to serve the public and private forestry sectors. Curriculum development for forestry education must be linked to natural resources development, potential business ventures and trade, environment in the community, scientific research, and respective country's need for forestry training, research and innovation agenda (Nair, 2004). In fact, participants from 29 countries at the international workshop on forestry education in 2007 , agreed to move towards holism and away from industrial-based forestry education models. They also recommended that foresters be re-trained in new approaches to forest management and review the objectives of forestry education in the light of future developments (Guariguata and Evans, 2010).

With the steady growth in community-based forestry and private forest ownership, on-line forestry education can serve wider audiences and deliver such programs in an innovative and efficient manner. This concept has been practiced in Cornell University's Forest-Connect program called as "webinar series". The outcome from the web survey showed positive response from the participants, who were encouraged to seek additional information as a result of viewing the webinar (Allred and Smallidge, 2010).

These findings suggest that a successful forestry education must be flexible to cope with the changing needs of the forestry sector. Although the social, economic and environmental realms of forestry practices remain the same, its focus changes according to local needs, which the professional forester must be capable of coping with. Failure to demonstrate this flexibility, from the perspective of the curricula as well as the academics, would render both irrelevant to the forestry sectors at large.

\section{Conclusions}

The global forestry education is in transition, and efforts must be taken to renew interests in forestry programs which would translate into higher student enrolments. There is an urgent need to restructure the traditional forestry curricula with a higher degree of flexibility, which allows forestry graduates to adapt to the changing workenvironment and market needs. The need for specialized skills among forestry graduates to cope with the forests that is increasingly playing non-traditional roles must be realized and incorporated into the curricula. Such forestry education programs will gain in relevance, viability and also visibility in the eyes of the forestry sector and the society at large.

\section{References}

Allred SB, Smallidge PJ (2010). An educational evaluation of web-based forestry education. J Extension 48(6):1-14.

Andersen F, Konijnendijk CC, Randrup TB (2002). Higher education on Urban Forestry in Europe: An Overview. For- estry 75(5):501-511.

Arevalo J, Mola-Yudego B, Pelkonen P, Qu M (2012). Students' view on forestry education: A cross-national comparison across three universities in Brazil, China and Finland. Forest Policy Econ 25:123-131.

Arevalo J, Pitkänen S, Gritten D, Tahvanainen L (2010). Marketrelevant competencies for professional foresters in European graduate education. Internat For Review 12(3):200-208.

Attah A, Ioras F, Abrudan IV, Ratnasingam J. (2009): The Voluntary partnership agreement: The Ghanaian and Malaysian experiences. Internat For Review 11(3):311-318.

Brown N (2003). A critical review of forestry education. Biosci Edu E-Journal 1(1):1-4.

Burley J (2001). Changing Forestry Education-A United Kingdom View. Paper presented at International University Forest Education Leaders, University of British Columbia, Vancouver, $11 \mathrm{p}$.

Daramola TM (2010). Forestry Education in Africa-State and Prospects. Outcome, of Discussion at the Northern African Regional Meeting of the International Forestry Students' Association (IFSA) at the 18th Commonwealth Forestry Conference. (www.cfc2010.org/papers/session8/Daramola-s8.pdf).

Department of Statistics Malaysia (2012). Forestry. (http:// www.statistics.gov.my/portal/download_Economics/files/ DATA_SERIES/2011/pdf/12Perhutanan.pdf)

Green CC (2006). Forestry Education in the United States. Issues in Science and Technology Librarianship, Supplement No. 46, 8 p.

Guariguata MR, Evans J (2010). Advancing tropical forestry curricula through non-timber forest products. Internat For Review 12(4):418-426.

Hadi Y (1977). Forestry Degree and Diploma Programme at University Pertanian Malaysia. In: Sastry CB, Srivastava PBL, Manap AA (eds.). A New Era in Malaysian Forestry. Selangor: Universiti Pertanian Malaysia Press.

Hahn-Schilling B (2004). The Professional Demand for Graduates of the School of International Tropical Forestry-Employer Survey in the Forest Sector of Sarawak. MalaysianGerman Forestry Education Project. Consultancy Report No. 3.

Hann-Schilling B (2005). The Professional Demand for Graduates of the School of International Tropical Forestry-Employer Survey in the Forest Sector of Peninsular Malaysia. Malaysian-German Forestry Education Project. Consultancy Report No. 5.

Innes JL (2005). Multidisciplinarity, interdisciplinarity and training in forestry and forest research. For Chronicle 81:324-329.

Innes JL, Ward D (2010). Professional Education in Forestry. Commonwealth Forestry Association. (http://www.naufrp.org/pdf/Professional\%20Education\%20in\%20Forestry. pdf). 
20

Kammesheidt L, Idrus RM, Trockenbrodt M, Hann-Schilling B (2007). Linking academic forestry education with employers' demand: A case study from Malaysia. Internat For Review 9(2):661-669.

Kanowski P (2001). Forestry Education in a changing landscape. Internat For Review 3:175-183.

Jomo KS, Chang YT, Khoo KJ (2004) Deforesting MalaysiaThe Political Economy and Social Ecology of Agricultural Expansion and Commercial Logging. London, Zed Book Publisher.

Leslie AD, Wilson ER, Starr CB (2006). Current state of professional forestry education in the United Kingdom. Internat For Review 8(3):339-349.

Miller H (1992). Trends in forestry education in Great Britain and Germany. Unasylva 55:29-32.

Nair CTS (2004). What does the future hold for forestry education? Unasylva 55:1-9.

Nyland RD (2008). The decline in forestry education enrolment-some observations and opinions. Bosque 29(2): 105108 .

Ratnasingam J, Reid HF, Perkins MC (1997). Furniture iIndustry-regaining the competitive edge. J Institute of Wood Sci $14(3): 115-120$.

Ratnasingam J, Ioras F (2006). Colonial British Forestry and the years thereafter. Kuala Lumpur: Tropical Resources Network Press.

Ratnasingam J, Ioras F (2007). Sustaining the South East Asian wood products sector through education-The German Lesson. J Instit of Wood Sci 17(5):254-258.

Ratnasingam J, Macpherson TH, Ioras F, Abrudan IV (2008) Chain of custody certification among Malaysian wooden furniture manufacturers: status and challenges. Internat For Review 10(1):23-28.

Ratnasingam J, Ioras F (2009). Foreign direct investments, added value and environmental friendly practices in furniture manufacturing-the case of Malaysia and Vietnam. Internat For Review 11(4):464-474.

Ratnasingam J, Wagner K, Scholz, F (2010). Human Capital Development for the Wood Products Sector. London, Centre for Economic Development.
Ratnasingam J, Mariappan M, Tan TS (2011). Malaysian Forestry-Past, Present and the Future. (E-Book downloable from www.forr.upm.edu.my) Selangor: University Putra Malaysia Press.

Ratnasingam J (2011). Employability of Forestry Graduates in Malaysia-Myths and Realities. Singapore: IFRG Report No. 14, 28 p.

Ratnasingam J (2012). The Malaysian Wood Products SectorUnder Siege. Kuala Lumpur: Special Report to Federation of Malaysian Manufacturers (FMM), 69 p.

Singham SS (1977). Forestry Education and Training in the Forestry Department, Peninsular Malaysia. In: Sastry CB, Srivastava PBL, Manap AA (eds.). A New Era in Malaysian Forestry, Selangor: Universiti Pertanian Malaysia Press.

Soeradji S (1977). Education in Wood Technology with Special Reference to Mara Institute of Technology. In: Sastry CB, Srivastava PBL, Manap AA (eds.). A New Era in Malaysian Forestry, Selangor: Universiti Pertanian Malaysia Press.

Storch S (2011). Forestry professionalism overrides gender: A case study of nature perception in Germany. Forestry Policy Econ 13:171-175.

Temu AB, Rudebjer PG, Kiyiapi J, Lierop PV (2005). Forestry Education in Sub-Saharan and Southeast Asia: Trends, Myths and Realities. FONP Working Paper No. 14.

Temu AB, Okali D, Bishaw B (2006). Forestry education, training and professional development in Africa. Internat For Review 8(1):118-125.

Trockenbrodt M (2003). Career Prospects and Professional Demand for Graduates of the School of International Tropical Forestry. Malaysia-German Forestry Education Project Consultancy Report No 1.

Vanclay J (1996). The future of forestry education. Instit of For of Austr Newsletter 37(2): 2-6.

Vanclay J (2005). Achieving a quiet revolution in forestry education. Australian Forest Grower, 25-26 p.

Vanclay J (2007). Educating Australian foresters for the $21^{\text {st }} \mathrm{cen}$ tury. Internat For Review 9(4): 884-891.

Wellman JD (1987). Images of a profession-forestry is something of a mystery to college bound students. J Forestry 85:18-19. 